\title{
Exploring Factors of Home Resources and Attitudes Towards Mathematics in Mathematics Achievement in South Korea, Turkey, and the United States
}

\author{
Rachel Louise Geesa ${ }^{1}$, Burcu Izci ${ }^{2}$, Hyuksoon Song ${ }^{3}$, Shiyi Chen ${ }^{4}$ \\ ${ }^{1}$ Ball State University, Muncie, USA \\ 2 Florida Gulf Coast University, Fort Myers, USA \\ ${ }^{3}$ Georgian Court University, Lakewood, USA \\ ${ }^{4}$ Florida State University, Tallahassee, USA
}

Received 8 May 2018 - Revised 25 November 2018 - Accepted 23 January 2019

\begin{abstract}
Educational opportunities and resources for students differ around the world. Trends in International Mathematics and Science Study (TIMSS) highlights students' achievement, home resources, and attitudes towards mathematics and science. In this study, we sought to identify home resources and attitudes towards mathematics factors that significantly predict fourth graders' mathematics achievement in South Korea, Turkey, and the United States using TIMSS 2015 data. Results indicated that home resources and attitudes towards mathematics both positively and significantly predicted students' mathematics achievement. Moreover, an interesting pattern emerged as Turkish students' attitudes towards mathematics were higher and mathematics achievement scores were lower than students from South Korea, and the United States. Future research may include longitudinal studies of mathematics achievement among the three countries.
\end{abstract}

Keywords: home resources, international education, mathematics achievement, attitudes, Trends in International Mathematics and Science Study (TIMSS)

\section{INTRODUCTION}

In the last decade, there has been increased global attention to student achievement in science, technology, engineering, and mathematics (STEM) fields. This emphasis has resulted in increased efforts to close the achievement gap between nations (Carnoy \& Rothstein, 2013). To expand knowledge and competencies in STEM fields, governments and ministries may seek more information about students' backgrounds to better understand the variance in mathematics achievement scores and identify methods for continuous growth and improvement in areas related to STEM. As a result, certain countries have participated in large scale, comparative studies (e.g., Trends in International Mathematics and Science Study [TIMSS], Programme from International Student Assessment [PISA], Progress in International Reading Literacy Study [PIRLS]) to examine factors that affect students' achievement and determine their ranks among their neighboring nations and other countries (IEA, 2017; OECD, 2016b; Paik, 2004). TIMSS, one of the large scale international studies at the fourth and eighth grades, was first administered in 1995. Since that time, policy makers, educators, and researchers have utilized TIMSS results to identify trends in mathematics and science achievement by country, measure the effectiveness of their educational systems among other nations, recognize possible weaknesses, and suggest reforms to improve their educational policies (e.g., Chen, 2014; Mullis, Martin, Foy, \& Hooper, 2016). Additionally, TIMSS data provide information for scholars and stakeholders to build knowledge about relations between students' home resources, education, and achievement in each participating country.

Mathematics is a discipline that affects students' success in academics and their future careers (Claessens, Duncan, \& Engel, 2009; Lubinski, Benbow, \& Kell, 2014). Early childhood and elementary school years, in particular,

(C) 2019 by the authors; licensee Modestum Ltd., UK. This article is an open access article distributed under the terms and conditions of the Creative Commons Attribution License (http://creativecommons.org/licenses/by/4.0/).

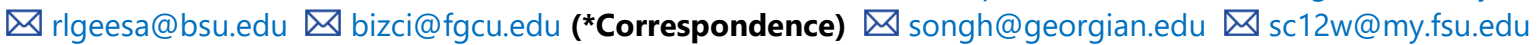




\section{Contribution of this paper to the literature}

- Our study makes an important contribution to a growing body of international comparative research studies by comparing home resources and attitudes towards mathematics predicting students' achievement in South Korea, Turkey, and the United States.

- Possible predictors of fourth graders' mathematics achievement are often neglected in the literature. Our study contributes to the literature by examining home resources and attitudes towards mathematics predicting fourth graders' mathematics achievement in TIMSS 2015.

- The importance of cultural differences and countries' emphasis on STEM education are highlighted in our study.

are formative years that students gain early mathematics skills. Students' foundational mathematics skills play a predictive role in their achievement in mathematics and other disciplines including reading and science from kindergarten through eighth grade (Claessens \& Engel, 2013). For example, Duncan et al. (2007) explored the contribution of the school-entry level (kindergarten) students' academic skills in mathematics and reading to their achievement in fifth grade. Students' early mathematics skills outperformed other variables such as early reading skills, attention, and social skills in predicting later mathematics and science achievement among those students. Similarly, other researchers found that elementary school students' knowledge of fractions and division uniquely predicts those students' high school achievement, controlling for other mathematics knowledge, working memory, and family income and education (Siegler et al., 2012). While concentrating on students' long-term future, Ritchie and Bates (2013) discovered that elementary students' mathematics achievement related to the students' career choices and socioeconomic status (SES) in adulthood.

With a focus on international mathematics achievement, TIMSS data provides scholars and stakeholders perspectives of students' mathematics achievement in relation to other countries' achievement rankings. In TIMSS 2015, fourth grade mathematics achievement scores differed among the 49 participating countries. For example, East Asian countries (Singapore, Hong Kong SAR, South Korea, Chinese Taipei, and Japan) were the highest achievers in fourth grade students' mathematics achievement. In addition, the achievement gap in mathematics between these five Asian countries and the next highest participating nation remained the same between the TIMSS 2011 and 2015 (Mullis, Martin, Foy, \& Arora, 2012; Mullis et al., 2016). East Asian countries' achievement in mathematics have received increased attention by researchers; as a result, various comparative studies are conducted to explore similarities and differences between Eastern and Western countries in students' mathematics achievement and learning-related factors (e.g., Chen, 2014; Leung, 2001, 2006; Linn, Lewis, Tsuchida, \& Songer, 2000).

The difference between students' achievement across countries could be related to a variety of factors including students' home resources, attitudes towards mathematics, and cultural differences. For example, students' home resources, such as the number of books at home and having a room or computer, help researchers to understand students' home contexts and how those resources are related to their mathematics achievement (Güvendir, 2014; Topçu, Erbilgin \& Arikan, 2016; Yayan \& Berberoglu, 2004). In TIMSS 2011, students' home resources were found to be associated with fourth graders' mathematics achievement (Mullis et al., 2012). Similarly, based on TIMSS 2015 data, students who had more home resources had higher achievement scores in mathematics, compared to their peers who had some or few resources in their homes (Mullis et al., 2016).

In addition to home resources, students' attitudes towards mathematics and their interest in learning mathematics affect their achievement in elementary school years (Akyüz, 2014; Topçu et al., 2016). Students who have negative attitudes towards mathematics attribute their attitudes to poor grades and previous failures. These students are more likely to avoid tasks involving mathematics or expect undesirable outcomes (Rowan-Kenyon, Swan, \& Creager, 2012). Cultural differences including parental perspectives or high stakes testing may affect students' achievement scores in mathematics, which play a predictive role in students' success in school and career choices in the future. For example, high stakes testing and competition in East Asian countries influence parents' perspectives and students' attitudes towards education (Byun, Schofer, \& Kim, 2012). The focus on private, additional education programs outside of the school day to increase test scores presents cross-cultural differences between families' involvement in their children's education and expectations for their achievement in Eastern countries such as South Korea and Western countries such as the United States and European countries (Lee, 2005, 2007; Stevenson \& Stigler, 1992).

Given the importance of students' mathematics skills in early elementary years, we specifically focused on the fourth graders' mathematics achievement in this study. To explore the possible factors affecting students' achievement in mathematics, we focused on three countries in which students' mathematics achievement varies in TIMSS 2015. The education systems and cultural characteristics in the selected three counties would be clearly 


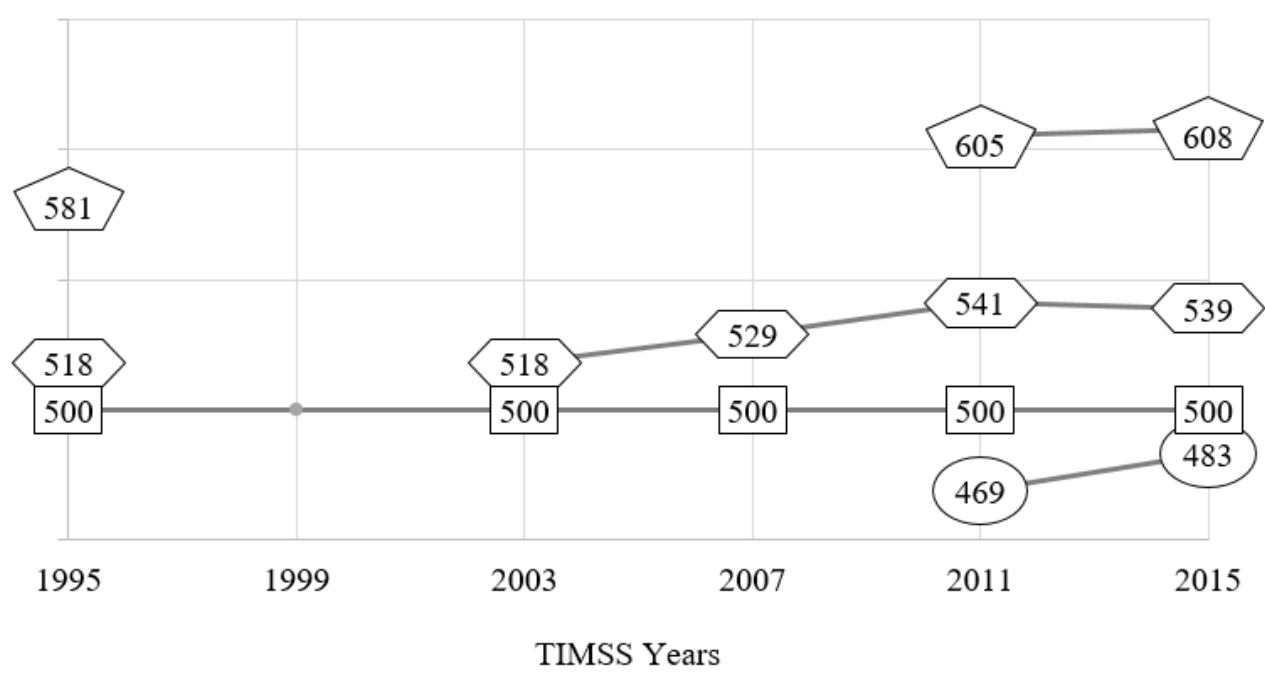

\section{$\square$ South Korea $\bigcirc$ Turkey $\square$ United States $\square$ International Average}

Figure 1. Fourth Graders' TIMSS Mathematics Achievement in South Korea, Turkey, and the United States Note. Data were collected from the TIMSS International Results in Mathematics reports (Mullis et al., 2012; Mullis et al., 2016) and indicate the average mathematics achievement scores by country (South Korea, Turkey, and the United States) and year. TIMSS is administered once every four years since 1995, but these countries did not participate each year that it was administered. In 1999, TIMSS was only administered to eighth grade students. The international average is the average score of all participating countries' mathematics achievement scores accepted by the TIMSS organizers.

understood and fairly explained by the authors. As presented in Figure 1, South Korea ${ }^{1}$ (one of the top achievers), Turkey (below the international average), and the United States ${ }^{2}$ (above the international average) have diverse achievement levels in mathematics. Although each of the three countries' mathematics achievement scores varied in rank among other nations, the scores from the individual countries have increased since the initial test administration in 1995 for South Korea and the United States, and since 2011 for Turkey when the country first participated in TIMSS (see Figure 1).

\section{THEORETICAL FRAMEWORK}

Students' ability to gain mathematics skills in early grades has been demonstrated to be a factor of their mathematics achievement in later years (Claessens \& Engel, 2013). It is widely acknowledged that students' mathematics achievement is influenced by a variety of factors, which include resources at home, socioeconomic status (SES), student behavior, and instruction (Manolitsis, Georgiou, \& Tziraki, 2013). Similarly, society and culture that students live in may affect their home environments as well as expectations from the students (Bronfenbrenner, 1994). In recent years, students are expected to be compatible in mathematics and other STEM disciplines regardless of their differences in home environments or attitudes towards subject areas. Related to this phenomenon, Bandura's Social Cognitive Theory and Bronfenbrenner's Ecological Theory guided our study. For example, Bandura's Social Cognitive Theory posits that people learn through observing, imitating, and modeling others in their environment (Bandura, 1986). We referenced this theory in our study, as it particularly emphasizes the continuous triadic reciprocal interaction among personal (cognitive-affective), behaviors, and environmental influences (Rosenthal \& Zimmerman, 1978). The thought and attitude that individuals have on the event can influence their environments, which in turn influence their subsequent performance, thought, and attitude. According to Social Cognitive Theory, "people are producers as well as products of environmental conditions" (Zimmerman \& Schunk, 2003, p.438).

In addition to Bandura's Social Cognitive Theory, this phenomenon can be also explained by Bronfenbrenner's Ecological Theory. During childhood years, the home is considered as children's immediate environment where

${ }^{1}$ South Korea is listed as Korea or Republic of Korea in the Trends in International Mathematics and Science Study (TIMSS). For consistency purposes, South Korea is used to represent Korea or Republic of Korea throughout this paper.

${ }_{2}^{2}$ In the TIMSS, the United States represents the United States of America or the USA. For consistency purposes, the United States is used to represent the United States of America or the USA throughout this paper.

Funding sources: This research did not receive specific grant from funding agencies in the public, commercial, or not-for-profit sectors. 
they learn from others and may have access to various resources such as books, computers, or other resources for their learning (Bronfenbrenner, 1994). Researchers identified that home environment and resources play a significant role in students' academic intrinsic motivation (Gottfried, Fleming, \& Gottfried, 1998), as well as students' achievement in mathematics (e.g., Akyüz, 2006, 2014; Chiu, 2010; DeFlorio \& Beliakoff, 2015). For instance, Chiu (2010) claimed that students have higher scores in mathematics if their family, school, and country have more resources. Recent studies also support the notion that students' home environment contribute to their learning and achievement in mathematics (e.g., Anders et al., 2010; Manolitsis et al., 2013; Melhuis et al., 2008), and further research is needed to better understand the relations between home resources and mathematics achievement.

Given the significance of research related to students' mathematics achievement, the purpose of this study was to identify home resources and attitudes towards mathematics factors and their contributions to fourth grade students' mathematics achievement in TIMSS 2015 for three countries: South Korea, Turkey, and the United States. Our decision to select home resources and attitudes as variables of interests stemmed from the theoretical framework. Students' attitudes towards mathematics and home resources correspond to the personal and environmental aspects in the triadic reciprocal model (Rosenthal \& Zimmerman, 1978). Attitudes towards mathematics include students' personal interests, perceived skill level, and perceived difficulty level of mathematics. Moreover, homes are one of the most immediate environments for individuals based on the Social Cognitive Theory (Bandura, 1986) and Ecological Theory (Bronfenbrenner, 1994). Therefore, we chose the home resources variable such as the number of books, private rooms, and computers to represent the environment factor. Our aim was to examine students' achievement across countries and understand possible predictors of students' mathematics achievement. In addition, our study contributes to the literature of cross-cultural comparison based on TIMSS data, similar to previously conducted research across various nations (e.g., Ramirez, 2006; Topçu et al., 2016; Wang, 2004).

\section{OVERVIEW OF EDUCATION SYSTEM AND MATHEMATICS CURRICULUM BY COUNTRY}

Educational opportunities at home, in school, and within communities differ throughout the world due to variables that may affect achievement (Chen, 2014; Zhu \& Leung, 2012). This difference is reflected in TIMSS reports in the last decade (Mullis et al., 2012, 2016). The design of educational programs and emphasis in students' learning in STEM disciplines differs in various countries based on their cultures, student populations, or education policies. South Korea (one of the top achievers), Turkey (below the international average), and the United States (above the international average) have diverse achievement levels in mathematics in TIMSS 2015. Additionally, our pedagogical knowledge and experiences with three cultures may provide a deeper understanding of the educational background of each of the three countries. Therefore, we share overviews of the education systems and mathematics curricula of the three countries in this study. By reviewing the overviews of education systems, including mathematics curricula in the selected countries, a more robust understanding of the types of educational structures in South Korea, Turkey, and the United States can be developed.

\section{South Korea}

South Korea has a 6-3-3-4 system of education: six years of elementary school, three years of middle school, three years of high school, and four years of college or university (Kim, 2008). Elementary and middle school is free and compulsory, and a national curriculum is applied to all students in elementary and middle school students (Sang, Kwak, Park, \& Park, 2016). According to the Korean Ministry of Education (2017a), 3.3 million students are enrolled in 5,855 elementary schools and 2 million students are enrolled in 3,144 middle schools. The South Korean national curriculum is revised periodically to reflect emerging needs of a rapidly changing society. In 2015, the South Korean governmental authority revised the national curriculum. This revised curriculum focuses learning on key competencies that creative and integrative learners should acquire, such as self-management competency, knowledge-information processing skills, creative thinking skills, aesthetic-emotional competency, communication skills, and civic competency (Korean Ministry of Education, 2017b).

In TIMSS 2011, South Korean fourth grade students ranked second in mathematics achievement, but fiftieth in attitudes towards mathematics (Mullis et al., 2012). Therefore, the South Korean government is focused on helping their students to be creative, integrative, motivated learners by developing their character and creativity competencies (OECD, 2016a). The 2015 revised mathematics curriculum focuses on easing stress on students and aims to allow students to be more creative and increase their capacity for data processing and the use of engineering tools. Additionally, the curriculum is designed to support students in building confidence in their mathematics abilities and learning more about the subject's practical applications (OECD, 2016a).

In addition to the curriculum of public education, education fever can be another factor in explaining South Korean students' high educational performance (Kim, Lee \& Park, 1993; Lee, 2003). Education fever in South Korea 
refers to the desire to focus intensively on academics and schoolwork. However, rather than being beneficial, education fever has a hidden dark side to this academic frenzy. Parents in South Korea believe if a child excels at studying in grade school, then he or she may be able to continue his or her education at a prestigious university. In South Korea, graduation from the highest ranked universities can be closely related to successful careers and lead to changes in political, economic, and social circumstances (Lee, 2006). Therefore, the South Korean competitive college entrance examination system increases out-of-school tutoring, private cram schools (hagwons), and online study providers, which is a growing industry (Choi \& Cho, 2016; Kim \& Park, 2010). It is very common for South Korean schoolchildren to attend one or more cram schools after their elementary school-day. Their private education, such as cram schools and private tutoring, may justify their higher performance in the standardized tests as well.

\section{Turkey}

Turkey has a 4-4-4 system of education including four years of elementary school, four years of middle school, and four years of high school. According to the Turkish Ministry of Education (2018), there were 5.1 million students in 24,967 elementary schools during the 2017-2018 school year. The Ministry of National Education provides educational and training activities for students in Turkey. Students, ages five to thirteen years old, obtain compulsory education in elementary and middle schools (Özdemir, Gönen, Polat, \& Akyüz Ari, 2016). The main objective of the mathematics curriculum in elementary school is to improve students' foundational mathematics skills as well as to help students develop the following competencies of problem solving, reasoning, using mathematics terms and models, and utilizing instructional tools, information, and communication technologies (Talim ve Terbiye Kurulu Başkanlığı, 2018). In 2018, the revised mathematics curriculum for first through fourth grades includes four learning areas: numbers and operations, geometry, measurement, and data analysis (Talim ve Terbiye Kurulu Başkanlığı, 2018).

Turkish fourth grade students participated in TIMSS in 2011 and 2015 (Mullis et al., 2016). In 2011, Turkey ranked 35th among 52 nations in fourth grade mathematics achievement with 469 points (Mullis et al., 2012). In 2015, Turkish students' achievement scores increased 14 points, but they ranked $36^{\text {th }}$ of 49 countries (Mullis et al., 2016). Even though fourth graders' mathematics achievement increased over time, their rank decreased. The increase in students' achievement scores could be explained by the popularity of STEM education and Turkish students' motivations for learning mathematics in recent years. The decrease in Turkish students' rank in TIMSS 2015, however, could be related to other countries' continuous efforts on STEM education and preparing their students to be qualified individuals in STEM disciplines in the last decade (Akgündüz et al., 2015).

Similar to other nations, Turkish policy makers and researchers began to focus on STEM education and take actions to improve instruction and student achievement in STEM fields. For example, since 2016, Turkish Ministry of National Education released a STEM education report, opened an online platform for teaching students coding lessons, and released a teacher manual for STEM education (Ministry of National Education, General Directorate of Innovation and Educational Technologies [YEĞİTEK], 2016, 2017, \& 2018). In addition, private universities began training teachers in STEM fields, financially supporting STEM-based research centers, and providing STEM education materials and curriculum for students and teachers (Bahçeşehir University, STEM Center [BAUSTEM], 2018).

\section{United States}

Public education is governed by each state, as education is decentralized in the United States (Malley, Neidorf, Arora, \& Kroeger, 2016). Public schools are free for students from kindergarten through the twelfth grade. Kindergarten is not compulsory in all states and the age that students begin school varies among states with the average age of five (Malley et al., 2016). According to the National Center for Education Statistics (2017), 35.6 million students attend prekindergarten through eighth grade. In addition to students who attend public schools, 5.2 million students attend private elementary and secondary schools during the regular school day (National Center for Education Statistics, 2017).

Mathematics curriculum varies throughout the United States, but mathematics standards tend to focus on using mathematics to explore real-world situations and to develop a more thorough understanding of mathematics terms and concepts to solve problems and think critically (California Department of Education, 2015; Malley et al., 2016). To increase consistent education curricula throughout the United States, 42 out of 50 states, the District of Columbia, four territories, and the Department of Defense Education Activity (DoDEA) have adopted the Common Core State Standards for Mathematics (CCSSM) to guide curriculum framework development (Common Core State Standards Initiative, 2017; Malley et al., 2016). Digital technologies, such as tablets and laptops, are used by students in schools and at home to support their learning in the United States (Cheung \& Slavin, 2011, 2013). Topics in mathematics 
curriculum for third through fifth grades in the United States may include numbers, geometry, and measurement and data (Common Core State Standards Initiative, 2017; Malley et al., 2016).

In the United States, STEM education has become a central focus in developing the next generation of workers. The United States Department of Education projects the percentage of STEM jobs will increase by 14 percent between 2010 and 2020 (U. S. Department of Education, 2015). The Every Student Succeeds Act (ESSA) and College and Career Readiness (CCR) initiatives further support the national drive towards students' success in STEM subjects (Council of Chief State School Officers, 2018; ESSA, 2015; Malin, Bragg, \& Hackmann, 2017). Stakeholders throughout the United States encourage and fund programs for students to have access to educational opportunities and resources in STEM-related fields. Due to the recent motivation to prepare students for success in careers and higher education, students' exposure to STEM disciplines have increased an early age in schools, at home, and throughout the community (Council of Chief State School Officers, 2018; ESSA, 2015; Malin et al., 2017).

\section{RESEARCH QUESTIONS}

To explore home resources and attitudes towards mathematics factors and student achievement between South Korea, Turkey, and the United States, we investigated the following research questions:

1. What are the differences in students' home resources and attitudes towards mathematics affecting students' success in mathematics in South Korea, Turkey, and the United States?

2. To what extent do the composite measures of home resources and attitudes towards mathematics affect students' success in the fourth grade in South Korea, Turkey, and the United States?

3. Out of the composite measures of home resources, which resources are significantly related to fourth grade students' mathematics achievement in South Korea, Turkey, and the United States?

\section{METHODS}

\section{Data Sources and Sample}

In this study, we analyzed TIMSS 2015 results for South Korea, Turkey, and the United States. Since the initial TIMSS was administered in 1995, fourth grade students in the United States have participated in TIMSS each year in contrast to students in South Korea and Turkey (see Figure 1). South Korea participated in TIMSS three times including in 1995, 2011, and 2015. Turkey, however, first participated in TIMSS in 2011 and continued in 2015. The participants in this study were a total of 21,154 fourth grade students in South Korea, Turkey, and the United States in TIMSS 2015. Data from TIMSS 2015 mathematics achievement and the student background questionnaire in South Korea, Turkey, and the United States were included for this study.

\section{Measures}

Publicly available data were collected via TIMSS 2015 International Database for South Korea, Turkey, and the United States and analyzed. Nine items under "Home resources" were selected from the student background questionnaire to constitute the home resources measure. The nine items used to measure home resources included: number of books, use of computers or tablets at home for homework, ownership of computers or tablets, sharing of computers/tablets, and having a desk, room, Internet connection, mobile phone, and gaming system at home. "Attitudes towards mathematics" was another variable of interest in the present study. Eighteen items measuring students' mathematics attitude and competencies were chosen to comprise attitudes towards mathematics (see Table 1). 
Table 1. Student Attitudes Towards Mathematics

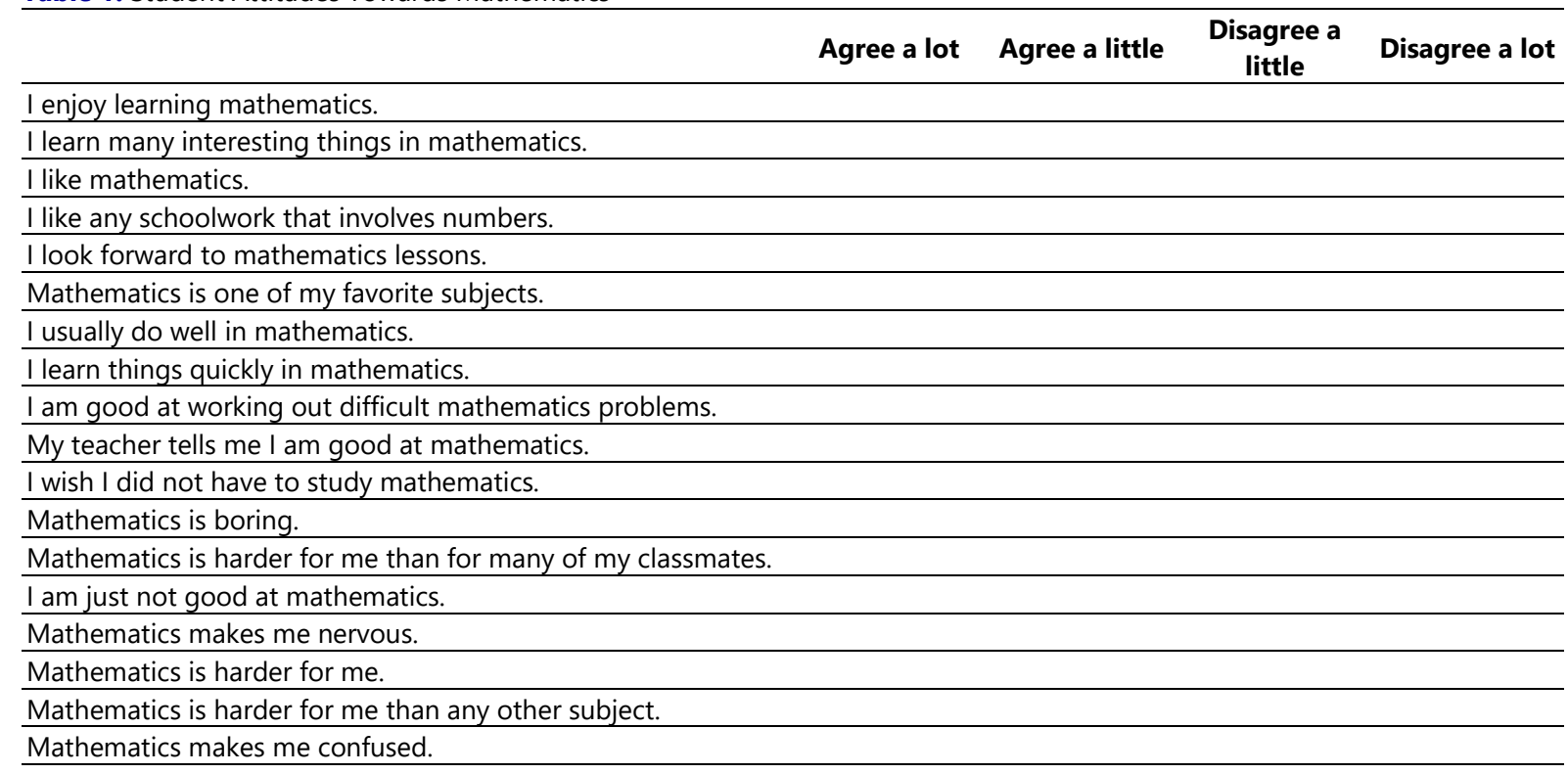

Negatively worded items were reversed coded. Plausible values in mathematics achievement were entered as outcome variables of mathematics achievement. Two composite variables of home resources and students' attitudes towards mathematics were created by aggregating scores to understand their predictive power on fourth graders' mathematics achievement in South Korea, Turkey, and the United States (Akyüz, 2014). We examined the student level factors including their home resources and attitudes toward mathematics. For this reason, statements measuring students' attitudes towards learning mathematics (i.e., How much do you agree with these statements about learning mathematics?) and mathematics in general (i.e., How much do you agree with these statements about mathematics?) are adapted from the TIMSS 2015 questionnaire of fourth grade students. The statements centering on students' attitudes towards mathematics lessons in the school are excluded because we focused on student level factors in our study. In the present study "attitudes towards mathematics" was composed of survey items that measured students' personal interests, perceived skill level, and perceived difficulty level of mathematics. "Home resources" was operationalized as tangible resources at home that may influence students' mathematics achievement (e.g., number of books, private rooms, tables, computers, tablets, and internet). A higher score on composite variables means a more positive mathematics attitude and more home resources. For this study, descriptive statistics and multiple regression analyses were conducted.

\section{Data Analysis}

A series of multiple linear regression analyses were conducted to examine contributions of attitudes towards mathematics and home resources to students' mathematics achievement. This data analysis method allowed us to explore relations between the outcome variables and a set of independent variables (Cohen, Cohen, West, \& Aiken, 2003). Data were cleaned and composite variables (i.e., attitudes towards mathematics and home resources) were created by aggregating scores in SPSS version 20. In order to measure the internal reliability of the home resources and attitudes towards mathematics composite variables, Cronbach's alpha coefficients were calculated by SPSS program. The items on the attitudes towards mathematics composite variable were found to be highly reliable (18 items; $\alpha=.93$ ), whereas Cronbach's alpha for the nine items of the home resources composite variable was .36.

Multiple regression was conducted by utilizing the International Association for the Evaluation of Educational Achievement (IEA) International Database (IDB) Analyzer (Version 3.1.17), which was developed to analyze data from IEA surveys to ensure the appropriate use of the complex plausible value technology (Foy, 2017; The IEA International Database Analyzer, 2013). Other advantages of using IDB Analyzer include the proper handling of complex sample designs of TIMSS data and more accurate standard error estimation. Compatible with SPSS, IDB Analyzer is able to conduct some common analysis such as correlation, analysis of variance, and linear regression. Results were produced as on-screen, SPSS data, and excel output files. For data analysis, composite variables of "home resources" and "attitudes towards mathematics" and five plausible variables of students' mathematics achievement were included. Linear regression was computed by using pairwise deletion for missing variables in the dataset. The missing data for composite variables are $10.2 \%(N=2157)$ for home resources composite variable and $12.4 \%(N=2614)$ for attitudes toward mathematics composite variable. 
Table 2. TIMSS 2015 Fourth Grade Mathematics Achievement Scores and Standard Errors for South Korea, Turkey, and the United States

\begin{tabular}{lcc}
\hline Country & TIMSS 2015 & Standard Errors \\
\hline South Korea $(N=4669)$ & 608 & 2.2 \\
\hline Turkey $(N=6456)$ & 483 & 3.1 \\
\hline United States $(N=10029)$ & 539 & 2.3 \\
\hline $\begin{array}{l}\text { Note. Data were collected from the TIMSS International Results in Mathematics report (Mullis et al., 2016). The international average (500) is the } \\
\text { average score of all participating countries mathematics' achievement scores accepted by the TIMSS organizers. TIMSS 2015 participants }(N) \text { are } \\
\text { indicated per country. }\end{array}$
\end{tabular}

Table 3. Descriptive Statistics of Fourth Graders' Home Resources in South Korea, Turkey, and the United States

\begin{tabular}{|c|c|c|c|c|c|c|c|c|c|}
\hline \multirow[b]{2}{*}{ Home Resources } & \multicolumn{3}{|c|}{$\begin{array}{l}\text { South Korea } \\
(N=4669)\end{array}$} & \multicolumn{3}{|c|}{$\begin{array}{c}\text { Turkey } \\
(N=6456)\end{array}$} & \multicolumn{3}{|c|}{$\begin{array}{c}\text { United States } \\
(\mathrm{N}=10029)\end{array}$} \\
\hline & $\mathbf{M}$ & S.E. & S.D. & M & S.E. & S.D. & $\mathbf{M}$ & S.E. & S.D. \\
\hline $\begin{array}{l}\text { Books (1: None/Very few; 2: One } \\
\text { Shelf; 3: Bookcase; 4: Two } \\
\text { Bookcases; 5: Three/More } \\
\text { Bookcases) }\end{array}$ & 4.04 & 0.03 & 1.09 & 2.40 & 0.03 & 1.09 & 2.90 & 0.02 & 1.20 \\
\hline $\begin{array}{l}\text { Use of computers/tablets at } \\
\text { home for homework } \\
\text { (1: Never/Almost never; } 2 \text { : } \\
\text { Once/Twice a month; } 3 \text { : } \\
\text { Once/Twice a week; } 4 \text { : Every } \\
\text { day/Almost every day) }\end{array}$ & 2.76 & 0.02 & 1.04 & 2.63 & 0.03 & 1.22 & 3.00 & 0.02 & 1.17 \\
\hline $\begin{array}{l}\text { Computers/tablets owned (0:No, } \\
\text { 1:Yes) }\end{array}$ & 0.22 & 0.01 & 0.42 & 0.56 & 0.01 & 0.50 & 0.77 & 0.01 & 0.42 \\
\hline Computers/tablets shared & 0.90 & 0.01 & 0.30 & 0.63 & 0.01 & 0.48 & 0.67 & 0.01 & 0.47 \\
\hline Desk & 0.87 & 0.01 & 0.34 & 0.69 & 0.01 & 0.46 & 0.67 & 0.01 & 0.47 \\
\hline Room & 0.55 & 0.01 & 0.50 & 0.52 & 0.01 & 0.50 & 0.68 & 0.01 & 0.47 \\
\hline Internet connection & 0.92 & 0.00 & 0.28 & 0.57 & 0.01 & 0.50 & 0.88 & 0.00 & 0.33 \\
\hline Mobile phone & 0.77 & 0.01 & 0.42 & 0.23 & 0.01 & 0.42 & 0.48 & 0.01 & 0.50 \\
\hline Gaming system & 0.52 & 0.01 & 0.50 & 0.25 & 0.01 & 0.43 & 0.87 & 0.00 & 0.34 \\
\hline
\end{tabular}

Descriptive statistics of home resources and attitudes toward mathematics were reported to answer research question 1 . To address research question 2, we examined the influence of attitudes towards mathematics and home resources composite variables on fourth grade students' mathematics achievements. Lastly, we conducted three multiple regressions using individual home resources variables as predictors to explore which home resources had greater impacts on fourth graders' mathematics achievement in three countries respectively to answer research question 3.

\section{RESULTS}

In TIMSS 2015, mathematics achievement scores for Turkey and the United States were consistently lower than scores for South Korea (Mullis et al., 2016) (see Table 2). Achievement scores in Turkey were below the international average, and scores in the United States were above the international average. Descriptive statistics of home resources and attitudes towards mathematics in South Korea, Turkey and the United States (see Table 3 and Table 4) and descriptive statistics of two composite variables were included in this section (see Table 5).

Based on the results, South Korean students had a higher number of resources at home $(M=11.57, S D=2.27)$, compared to their peers in the United States $(M=10.99, S D=2.40)$ and Turkey $(M=8.55, S D=2.92)$ (see Table 5). South Korean students had more books, and they were more likely to share a computer or tablet at home. A higher percentage of South Korean students had an internet connection, a desk, and a mobile phone (see Table 3). Similarly, the amount of United States' students' home resources were more than Turkish students' resources at home (see Table 3 and Table 5). Compared to South Korean and Turkish students, a higher percentage of United States' students had a tablet or computer, room, and gaming system at home and frequently used the computer or tablet for their homework. 
Table 4. Descriptive Statistics of Fourth Graders' Attitudes Towards Mathematics in South Korea, Turkey, and the United States

\begin{tabular}{|c|c|c|c|c|c|c|c|c|c|}
\hline \multirow[b]{2}{*}{ Attitudes Towards Mathematics } & \multicolumn{3}{|c|}{$\begin{array}{l}\text { South Korea } \\
(N=4669)\end{array}$} & \multicolumn{3}{|c|}{$\begin{array}{c}\text { Turkey } \\
(N=6456)\end{array}$} & \multicolumn{3}{|c|}{$\begin{array}{l}\text { United States } \\
(N=10029)\end{array}$} \\
\hline & $\mathrm{M}$ & S.E & S.D. & $\mathrm{M}$ & S.E & S.D. & $\mathrm{M}$ & S.E & S.D. \\
\hline $\begin{array}{l}\text { I enjoy learning mathematics. } \\
\text { (4: Agree a lot; } 1 \text { : Disagree a lot) }\end{array}$ & 2.95 & 0.02 & 0.85 & 3.83 & 0.01 & 0.51 & 3.26 & 0.02 & 0.95 \\
\hline I learn many interesting things in mathematics. & 3.05 & 0.02 & 0.81 & 3.74 & 0.01 & 0.71 & 3.46 & 0.01 & 0.87 \\
\hline I like mathematics. & 2.81 & 0.02 & 0.94 & 3.81 & 0.01 & 0.57 & 3.21 & 0.02 & 1.03 \\
\hline I like any schoolwork that involves numbers. & 2.67 & 0.02 & 0.92 & 3.78 & 0.01 & 0.59 & 2.91 & 0.02 & 1.06 \\
\hline I like to solve mathematics problems. & 2.72 & 0.02 & 0.94 & 3.71 & 0.01 & 0.66 & 3.12 & 0.02 & 1.04 \\
\hline I look forward to mathematics lessons. & 2.31 & 0.02 & 0.88 & 3.55 & 0.02 & 0.79 & 2.96 & 0.02 & 1.08 \\
\hline Mathematics is one of my favorite subjects. & 2.46 & 0.02 & 1.04 & 3.67 & 0.01 & 0.73 & 2.97 & 0.02 & 1.18 \\
\hline I usually do well in mathematics. & 2.82 & 0.02 & 0.81 & 3.61 & 0.01 & 0.65 & 3.36 & 0.01 & 0.84 \\
\hline I learn things quickly in mathematics. & 2.84 & 0.02 & 0.84 & 3.55 & 0.02 & 0.74 & 3.12 & 0.01 & 0.98 \\
\hline $\begin{array}{l}\text { I am good at working out difficult } \\
\text { mathematics problems. }\end{array}$ & 2.56 & 0.02 & 0.85 & 3.19 & 0.02 & 0.90 & 2.95 & 0.02 & 1.04 \\
\hline My teacher tells me I am good at mathematics. & 2.38 & 0.02 & 0.81 & 3.34 & 0.02 & 0.83 & 3.14 & 0.02 & 0.98 \\
\hline $\begin{array}{l}\text { I wish I did not have to study mathematics. } \\
\text { (1: Agree a lot; } 4 \text { : Disagree a lot) }\end{array}$ & 3.04 & 0.02 & 0.89 & 3.62 & 0.02 & 0.90 & 2.90 & 0.02 & 1.17 \\
\hline Mathematics is boring. & 2.97 & 0.02 & 0.88 & 3.62 & 0.02 & 0.86 & 3.03 & 0.02 & 1.11 \\
\hline $\begin{array}{l}\text { Mathematics is harder for me than for many of my } \\
\text { classmates. }\end{array}$ & 3.09 & 0.02 & 0.82 & 2.98 & 0.03 & 1.20 & 2.90 & 0.01 & 1.13 \\
\hline I am just not good at mathematics. & 2.61 & 0.02 & 0.84 & 3.22 & 0.03 & 1.10 & 3.19 & 0.02 & 1.07 \\
\hline Mathematics makes me nervous. & 2.74 & 0.02 & 0.94 & 2.81 & 0.03 & 1.28 & 2.95 & 0.01 & 1.12 \\
\hline $\begin{array}{l}\text { Mathematics is harder for me. } \\
\text { than any other subject. }\end{array}$ & 2.86 & 0.02 & 0.98 & 2.88 & 0.03 & 1.26 & 3.04 & 0.02 & 1.16 \\
\hline Mathematics makes me confused. & 2.73 & 0.02 & 0.98 & 3.11 & 0.03 & 1.17 & 2.91 & 0.02 & 1.13 \\
\hline
\end{tabular}

Note. Data were collected from the TIMSS International Results in Mathematics report (Mullis et al., 2016).

Table 5. Statistics of the Composite Variables for Fourth Graders in South Korea, Turkey, and the United States

\begin{tabular}{|c|c|c|c|c|c|c|}
\hline \multirow[b]{2}{*}{ Composite Variables } & \multicolumn{2}{|c|}{$\begin{array}{c}\text { South Korea } \\
(N=4669)\end{array}$} & \multicolumn{2}{|c|}{$\begin{array}{c}\text { Turkey } \\
(N=6456)\end{array}$} & \multicolumn{2}{|c|}{$\begin{array}{c}\text { United States } \\
(N=10029)\end{array}$} \\
\hline & $\mathbf{M}$ & S.D & $\mathbf{M}$ & S.D & $\mathbf{M}$ & S.D \\
\hline $\begin{array}{l}\text { Home Resources } \\
\text { (2: Minimum; 16: Maximum) }\end{array}$ & 11.57 & 2.266 & 8.55 & 2.924 & 10.99 & 2.402 \\
\hline $\begin{array}{l}\text { Attitudes Towards Mathematics } \\
\text { (18: Minimum; 72: Maximum) }\end{array}$ & 49.69 & 11.260 & 62.41 & 8.842 & 55.64 & 12.722 \\
\hline
\end{tabular}

As opposed to ownership of home resources, Turkish students had higher attitudes towards mathematics $(M=62.41, S D=8.84)$ compared to their peers in South Korea $(M=49.69, S D=11.26)$ and the United States $(M=55.64$, $S D=12.72$ ) (see Table 5). Findings indicated that fourth graders in Turkey had more positive attitudes towards mathematics, and they experienced fewer problems or concerns with mathematics (see Table 4). Interestingly, we found that Turkish students reported the highest attitudes towards mathematics while their mathematics scores were the lowest among the three nations. In comparison, South Korean students had the lowest score of attitudes towards mathematics, but the highest mathematics achievement among the three countries (see Table 5). When examining individual attitude items, South Korean students scored lower on all positive and most negative items as compared to students from Turkey and the United States. The only negative item that South Korean students scored higher than the other two countries on is "Mathematics is harder for me than for many of my classmates."

\section{South Korea}

The regression model indicated that home resources and attitudes towards mathematics significantly predicted South Korean fourth grade students' mathematics achievement. Relatively moderate amounts of variance in student's mathematics achievement were explained by the model $\left(R_{S K}^{2}=.29\right)$. Compared to home resources, attitudes towards mathematics was better in predicting fourth grade students' mathematics achievement in South Korea $\left(\beta_{M S K}=.44, \beta_{H S K}=.24\right)$ (see Table 6). 
Table 6. Multiple Regression Results with Home Resources and Attitudes Towards Mathematics as Predictors by Countries

\begin{tabular}{|c|c|c|c|c|}
\hline & & $\beta$ Coefficient & $\begin{array}{c}\text { Standardized } \beta \\
\text { Coefficient }\end{array}$ & $t$ \\
\hline \multirow{3}{*}{ South Korea } & Home Resources $(\mathrm{N}=4575)$ & 7.22 & .24 & $12.80^{\star \star}$ \\
\hline & $\begin{array}{l}\text { Attitudes Towards } \\
\text { Mathematics } \\
(\mathrm{N}=4436)\end{array}$ & 2.63 & .44 & $26.59^{\star *}$ \\
\hline & $\begin{array}{l}\text { Home Resources } \\
(\mathrm{N}=5254)\end{array}$ & 8.85 & .27 & $10.84^{\star \star}$ \\
\hline Turkey & $\begin{array}{l}\text { Attitudes Towards } \\
\text { Mathematics } \\
(\mathrm{N}=5734)\end{array}$ & 4.41 & .41 & $26.41^{\star *}$ \\
\hline \multirow[b]{2}{*}{ United States } & $\begin{array}{l}\text { Home Resources } \\
(\mathrm{N}=9168)\end{array}$ & 4.89 & .14 & $12.16^{\star *}$ \\
\hline & $\begin{array}{l}\text { Attitudes Towards } \\
\text { Mathematics } \\
(\mathrm{N}=8370)\end{array}$ & 1.97 & .31 & $22.79^{* *}$ \\
\hline
\end{tabular}

Table 7. Multiple Regression Results with Home Resources Items as Predictors by Countries

\begin{tabular}{|c|c|c|c|c|}
\hline & & $\beta$ Coefficient & $\begin{array}{l}\text { Standardized } \beta \\
\text { Coefficient }\end{array}$ & $\boldsymbol{t}$ \\
\hline \multirow{9}{*}{ South Korea } & Books & 21.37 & .35 & $16.60^{\star \star *}$ \\
\hline & $\begin{array}{l}\text { Use of computers/tablets at home } \\
\text { for homework }\end{array}$ & -.32 & .00 & -.33 \\
\hline & Computers/tablets owned & -5.97 & -.04 & $-1.97^{\star \star}$ \\
\hline & Computers/tablets shared & 28.06 & .12 & $6.68^{\star \star \star *}$ \\
\hline & Desk & 12.11 & .06 & $3.52^{\star \star \star}$ \\
\hline & Room & 8.68 & .06 & $3.40^{\star \star \star}$ \\
\hline & Internet connection & 25.58 & .11 & $5.34^{\star \star \star}$ \\
\hline & Mobile phone & -2.05 & -.01 & -.75 \\
\hline & Gaming system & 3.38 & .03 & 1.67 \\
\hline \multirow{9}{*}{ Turkey } & Books & 20.04 & .24 & $11.26^{\star \star \star}$ \\
\hline & $\begin{array}{l}\text { Use of computers/tablets at home } \\
\text { for homework }\end{array}$ & -5.77 & -.08 & $-4.05^{\star \star \star}$ \\
\hline & Computers/tablets owned & 8.33 & .04 & $2.35^{*}$ \\
\hline & Computers/tablets shared & 29.75 & .16 & $9.29^{\star \star \star}$ \\
\hline & Desk & 13.01 & .06 & $3.73^{\star \star \star}$ \\
\hline & Room & 3.82 & .02 & 1.05 \\
\hline & Internet connection & 26.84 & .14 & $6.66^{\star \star \star}$ \\
\hline & Mobile phone & -4.37 & -.02 & -1.51 \\
\hline & Gaming system & -14.51 & -.07 & $-4.33^{\star \star \star}$ \\
\hline \multirow{9}{*}{ United States } & Books & 16.29 & .24 & $17.68^{\star \star \star}$ \\
\hline & $\begin{array}{l}\text { Use of computers/tablets at home } \\
\text { for homework }\end{array}$ & -9.27 & -.13 & $-10.25^{\star \star \star}$ \\
\hline & Computers/tablets owned & -3.54 & -.02 & -1.39 \\
\hline & Computers/tablets shared & 22.72 & .13 & $11.41^{\star \star \star}$ \\
\hline & Desk & 10.48 & .06 & $5.06^{\star \star \star}$ \\
\hline & Room & 8.66 & .05 & $3.99^{\star * *}$ \\
\hline & Internet connection & 40.03 & .16 & $13.31^{\star \star \star}$ \\
\hline & Mobile phone & -22.20 & -.14 & $-12.39^{* * *}$ \\
\hline & Gaming system & 9.42 & .04 & $3.25^{\star *}$ \\
\hline
\end{tabular}

Note. ${ }^{*} \rho<.05,{ }^{* *} \rho<.01,{ }^{* * *} \rho<.001$

When taking a closer scrutiny into contributions of individual home resources in predicting students' mathematics achievement (see Table 7), we found that the number of "books at home" was the strongest predictor in South Korea $\left(\beta_{B S K}=.35\right)$. On the other hand, owning a computer or tablet negatively predicted mathematics scores in South Korea $\left(\beta_{\text {CTSK }}=-.04\right)$. The more the computers/tablets were shared at home, students seemed to have higher mathematics scores in South Korea $\left(\beta_{C T S S K}=.12\right)$. Using a computer or tablet at home for homework, owning 
cell phones, and owning gaming systems were not significant predictors. On the contrary, having a desk, a private room, and an internet connection demonstrated a small but significant positive predict in South Korea.

\section{Turkey}

In this model, attitudes towards mathematics and home resources significantly predicted fourth grade students' mathematics achievement in Turkey (see Table 6). Relatively moderate amounts of variance in student's mathematics achievement were explained by the model $\left(R_{T}^{2}=.26\right)$. Attitudes towards mathematics were better in predicting fourth grade students' mathematics achievement in Turkey as compared to home resources $\left(\beta_{M T}=\right.$ $\left..41, \beta_{H T}=.27\right)$. When examining contributions of specific home resources in predicting students' mathematics achievement (see Table 7), we found that the number of books at home was the strongest predictor in Turkey $\left(\beta_{B T}=\right.$ .24). In comparison, owning a computer or tablet negatively predicted mathematics scores in Turkey $\left(\beta_{\text {CTSK }}=-.04\right)$.

Similar to South Korea, the more the computers/tablets were shared at home, students seemed to have higher mathematics scores in Turkey $\left(\beta_{\text {CTST }}=.16\right)$. Relatedly, using a computer or tablet at home for homework negatively predicted students' mathematics achievement in Turkey $\left(\beta_{C H T}=-.08\right)$. Owning gaming systems demonstrated a weak, but a significant negative effect in predicting mathematics achievement in Turkey $\left(\beta_{G S T}=-.07\right)$, whereas owning a cellphone was not a significant predictor in Turkey. Additionally, having a desk and internet connection demonstrated small but significant positive predictive power in students' mathematics achievement in Turkey.

\section{United States}

Like the other two countries, attitudes towards mathematics and home resources significantly predicted fourth grade students' mathematics achievement in United States (see Table 6). Relatively small amounts of variance in students' mathematics achievement were explained by the model $\left(R_{U S}^{2}=.12\right)$. Compared to home resources, attitudes towards mathematics was better in predicting fourth grade students' mathematics achievement in United States $\left(\beta_{M U S}=.31, \beta_{H U S}=.14\right)$. When looking into contributions of individual home resources in predicting students' mathematics achievement (see Table 7), we found that the number of books at home, similar in the other two countries, was the strongest predictor in the United States $\left(\beta_{B U S}=.24\right)$.

Owning a computer or tablet was not a significant predictor in the United States. Consistent with the other two countries, the more the computers/tablets were shared at home, students seemed to have higher mathematics scores in the United States $\left(\beta_{\text {CTSUS }}=.13\right)$. Similar to Turkey, using a computer or tablet at home for homework and owning a cellphone negatively predicted students' mathematics achievement in the United States $\left(\beta_{\text {CHUS }}=-.13\right.$; $\left.\beta_{P U S}=-.14\right)$. Owning gaming systems demonstrated a weak, but significant positive effect in predicting mathematics achievement $\left(\beta_{\text {GSUS }}=.04\right)$. Moreover, having a desk, a private room, and an internet connection demonstrated small but significant positive predictive power to students' mathematics achievement in the United States.

In summary, attitudes towards mathematics and home resources were significant in predicting fourth grade students' mathematics achievement in all countries. Data analysis indicated some common patterns across three countries. Specifically, attitudes towards mathematics were better than home resources were in predicting students' mathematics achievement. The number of books at home was the strongest predictor as compared to other home resources. In contrast, the influence of electronic devices on mathematics achievement varied among the three countries, but a common pattern could be observed. Across three countries, it seemed that the fewer computers/tablets were owned by individuals in a household, the higher the fourth grade students' mathematics achievements might be. The next section includes a discussion of the results in terms of students' attitudes towards mathematics, the number of books in the household, home resources, cultural differences, and STEM education.

\section{DISCUSSION}

This study contributes to a growing body of international comparative research studies by comparing home resources and students' attitudes predicting fourth grade students' mathematics achievement in South Korea, Turkey, and the United States. Similarities and differences among the three countries emerged in terms of predictors of student achievement. The results of this study indicated the importance of both attitudes towards mathematics and home resources in students' mathematics achievement, which is consistent with previous findings (e.g., Akyüz, 2014; Topçu et al., 2016). Attitudes towards mathematics demonstrated stronger predict power as compared to home resources in predicting fourth grade students' mathematics achievement across South Korea, Turkey, and the United States. A pattern emerged regarding students' lower attitudes towards mathematics in higher achieving countries. We identified additional patterns in attitudes towards mathematics and home resources among these three countries, which are described in the following subheadings. 


\section{Attitudes Towards Mathematics}

One common finding across the three countries is students' attitudes towards mathematics. Our findings were consistent with Topçu et al.'s study (2016) in which Turkish and South Korean students' mathematics achievement was compared in TIMSS 2011. The findings showed that when students' attitudes towards mathematics increase, they have higher mathematics achievement. This pattern can be explained in Social Cognitive Theory. According to Social Cognitive Theory, students who have positive attitudes towards learning are more likely to have higher confidence in tasks and show better performance (Bandura, 1986; Rowan-Kenyon et al., 2012). Many previous empirical evidence showed that students' high attitudes towards mathematics are closely related to their motivation to accept challenges, take risks, and work longer to attempt to achieve higher scores (Brunning \& Horn, 2000; Bryant, 2017; Zimmerman, 2000). The contribution of attitude towards mathematics achievement suggests that it is worthwhile for mathematics educators to cultivate students' positive attitudes towards mathematics.

An interesting pattern was revealed in our study when comparing student attitudes towards mathematics. In TIMSS 2015, South Korean students had the least positive attitudes towards mathematics, but they had the highest mathematics achievement amongst the three countries. This paradoxical pattern regarding the relation between attitude and achievement across countries has been found in the previous research on TIMSS data. For instance, Papanastasiou (2000) compared students' mathematics attitude and their mathematics achievement in Cyprus, the United States, and Japan. Results showed that Japanese students had the highest achievement scores and the lowest attitude scores amongst those three countries. This pattern indicates a complex dynamic between cognitive factors (e.g., mathematics related knowledge and skills) and affective factors (e.g., attitudes and beliefs towards mathematics) (Papanastasiou, 2000). Cultural factors could also play a role in this phenomenon, which is discussed in a later section.

\section{Books in the Household}

Another common pattern observed across the three countries was that the number of books owned, which was a stronger predictor compared to other home resources in predicting fourth grade students' mathematics achievement. Güvendir (2014) also came to a similar conclusion that students who had more books at home were more likely to have a higher mathematics score. For example, in a study when eighth grade students' achievement was considered, Yayan and Berberoglu (2004) found a positive correlation between the number of books at home and mathematics achievement. The findings are also explained by Bandura's Social Cognitive Theory (Bandura, 1986), as well as Bronfenbrenner's Ecological Theory (Bronfenbrenner, 1994). Since both Social Cognitive Theory and Ecological Theory emphasize the role of environmental factors, such as the home resources which includes students' accessibility to books can be one of the positive factors in their learning performance. Therefore, we concluded that the number of books might be positively associated with achievement in mathematics due to students' accessibility to books at home and support from their families.

\section{Home Resources}

The impact of electronic devices (e.g., computer/tablet) on fourth grade students' mathematics achievement was relatively small compared to the number of books at home. However, data revealed an interesting pattern of the influence of electronic devices on mathematics scores. For example, students' use of computer/tablet for homework at home negatively predicted mathematics achievement (small to moderate effect in Turkey and the United States; no effect in South Korea), which indicates the fewer computers/tablets owned by individuals, the higher fourth grade students' mathematics scores. Topçu et al. (2016) also found relationships between the ownership of home resources and computer use at home in students' mathematics achievement. We concluded that possessing more electronic devices and using them for homework might impair fourth grade students' mathematics achievement. In line with our finding, Xu (2015) reported that technology distractions (e.g., distractions from computer, tablet, phones, etc.) were negatively related to students' mathematics homework effort and value beliefs. Our findings regarding the potential negative impact on technology usage on mathematics achievement were also consistent with an international report of relations between students' learning and computer usage from the Organisation for Economic Co-operation and Development (OECD, 2015).

Having internet connections at home also consistently and positively predicted students' mathematics achievements across South Korea, Turkey, and the United States. This could be due to the fact that students with internet connections at home are able to seek additional academic help via online resources (Skryabin, Zhang, Liu, \& Zhang, 2015). Other electronic devices, such as mobile phones and gaming systems, contribute differently across the three countries. For instance, owning a mobile phone weakly and negatively predicted fourth grade students' mathematics achievement in the United States, however, owning a mobile phone was not a significant predictor South Korea and Turkey. The negative influence of mobile phone could be viewed as a technology distraction, which is related to students' effort and value associated with mathematics homework $(\mathrm{Xu}, 2015)$. Upon closer 
scrutiny, the percentage of elementary students' the mobile phone ownership in South Korea trumps that of Turkey and the United States [i.e., South Korea: 90\% (Byun et al., 2013); Turkey: 40\% (Gönener, Galata, Sertbaş, \& Cander, 2014); and United States: 53\% (Poll, 2014)], to which some researchers suggest that phone usage habit and parental control play a role in the influence of mobile devices on academic outcomes (Livingstone, Mascheroni, Dreier, Chaudron, \& Lagae, 2015).

\section{Cultural Differences}

Aside from the common trends listed above, some predictors' strength and directions differed across countries. These variabilities may be associated with unique cultural and political backgrounds and expectations in three countries. For the case of South Korea, even though the students' mathematics achievement was the highest among the three countries, their attitudes towards mathematics were low. When looking at subscales of attitudes, it is found that South Korean students scored lower on both positive and negative items than students in Turkey and the United States. This unique pattern may be associated with the country's high standards of academic excellence. East Asian parents including South Korean parents have higher expectations for their children than European American and Latino parents (Okagaki \& Frensch, 1998). In addition, South Korean students have a strong sense of gratitude and indebtedness to their parents (Park \& Kim, 2006). High parental standards, as well as a strong sense of obligation, could increase the pressure to achieve and affect students' attitudes towards mathematics in general. Also, the negative effects of education fever such as too much stress on students about high stakes testing may influence their low attitudes in academic performance.

Additionally, "modest bias", which refers to perception differences rooted in cultures in assessing one's own abilities (Min, Cortina, \& Miller, 2016), may also explain the contradictory relation between attitude and achievement at the individual and the country level. Min et al. (2016) examined the effect of modest bias in mathematics achievement using three TIMSS datasets from 2003 to 2011. The researchers conducted a hierarchical linear regression model by adding the average self-concept and mathematics-enjoyment at country-level, which significantly reduced the negative association between mathematics attitudes and achievement at the country level. Their finding supports the idea that the attitude-achievement paradox across each country could be explained by cultural response bias (i.e., a high-achieving country has more salient modest norms and lower mathematics enjoyment).

\section{STEM Education}

Differences in mathematics achievements among three countries may lay in STEM education tradition and attempts in South Korea, Turkey, and the United States. TIMSS provides countries with thorough data regarding students' mathematics and science achievement levels, and national initiatives to promote STEM education are growing. South Korea and the United States began focusing on STEM disciplines for students more than two decades ago (Jho, Hong, \& Song, 2016; Kim \& Chae, 2016), as they first participated in TIMSS in 1995. A longstanding tradition of participating in TIMSS reflects South Korea and the United States' emphasis on STEM education in educational policies. For instance, federal agencies in the United States funded \$3.4 billion for STEM education programs and organizations in 2010 despite a recent national economic crisis (Douglas \& Strobel, 2015; National Science and Technology Council, 2011).

In contrast to South Korea and the United States, Turkey began participating in TIMSS at the fourth grade in 2011 and recognized the necessity of STEM education only recently, which may shed light on the mathematics achievement gap between Turkey and the other two countries. During the past five years, the Turkish government initiated a series of efforts to benefit STEM education. For instance, one of the first initiatives in Turkey was the Movement of Enhancing Opportunities and Improving Technology or FATIH Project, where public school students received free tablet computers to gain $21^{\text {st }}$ century skills (Pouezevara, Dincer, Kipp, \& Sariisik, 2013). In 2016, the Ministry of National Education of Turkey released a report citing possible actions to take for STEM education growth in the forthcoming years, such as establishing STEM education centers, conducting STEM education research, training STEM teachers, creating STEM education environments, and providing necessary laboratory materials to schools (YEĞITEK, 2016). Since that time, there are promising attempts to support STEM education, provide educational materials and include compulsory coding lessons into the national curriculum (YEĞITEK, 2016, 2017 \& 2018).

\section{LIMITATIONS}

This study is not without limitations. First, we only selected three countries for the present study. These three countries represented three different mathematics achievement level and three vastly different cultures in different areas of the world. To further investigate the phenomenon that high-achieving students in a collective culture have 
fewer positive attitudes towards mathematics, future studies need to examine students' attitudes towards mathematics in other Asian countries. Moreover, our study did not take the measurement invariance issue into account. As we addressed earlier, it is possible that the negative association of mathematics attitude and achievement at the country level could be due to the fact that students from various cultures perceive their mathematic competence and enjoyment differently. Therefore, the reliability of the measurement could be compromised due to the modest bias (Min et al., 2016). On a related issue, the current study utilized several linear regressions to explore relations among home resources, attitudes towards mathematics, and mathematics achievement in three countries separately. Future international comparative studies may consider using a multilevel regression approach and introduce national average academic self-concept/attitude at the country level in order to control the modest bias.

\section{CONCLUSIONS}

Research in education provides opportunities to review and guide educational policies, programs, and practices to better meet students' needs (Ordoñez \& Maclean, 1997; Zhu \& Leung, 2012). Analyses of students' home resources and attitudes towards mathematics can support the identification of equitable educational opportunities for all students to achieve in mathematics. Education policy makers often refer to TIMSS and similar international standardized test results when making decisions about mathematics educational plans and program funding to improve learning and achievement for students (Caponera \& Losito, 2016).

It is well established that mathematics education and the culture of teaching and learning at home and in school vary between countries. In this study, we compared home resources and attitudes towards mathematics factors related to fourth grade students' mathematics achievement in South Korea, Turkey, and the United States. South Korean students' mathematics achievement scores were the highest of the three nations, and students in South Korea had the most number of books in their households. Interestingly, Turkish students reported higher attitudes towards mathematics than South Korean or United States students reported despite Turkish students' mathematics achievement scores being the lowest of the three countries. This phenomenon may be associated with educational practice traditions and cultural differences among the three countries (Bryant, 2017). In the United States, students achieved higher and had more resources than Turkish students. United States students' attitudes towards mathematics were lower than Turkish students' attitudes towards mathematics, however.

We developed new knowledge from our analyses of TIMSS data, which builds opportunities for global educational scholars and policy makers to cultivate a deeper understanding of the relations between home resources and attitudes towards mathematics and mathematics achievement in South Korea, Turkey, and the United States. The conclusions of the study indicate that the participating countries could achieve improved results by using more efforts to communicate these findings to school administrators, teachers, and parents who are most directly in position to achieve positive change. In addition, longitudinal studies of mathematics achievement among the three countries may be included in future studies. Additionally, other factors that may impact students' mathematics achievement (e.g., motivations, cultural beliefs) should be explored since differences in these factors may affect other aspects of achievement and education (Zhu \& Leung, 2011). Although South Korea, Turkey, and the United States are included in this particular study, opportunities to expand this international comparative research to include other countries in the future do exist.

\section{REFERENCES}

Akgündüz, D., Aydeniz, M., Çakmakçı, G., Çavaş, B., Corlu, M. S., Öner, T., \& Özdemir, S. (2015). STEM eğitimi Tü̈kiye raporu: Günü̆ modası mı yoksa gereksinim mi? [A report on STEM Education in Turkey: A provisional agenda or a necessity?] [White Paper]. İstanbul, Turkey: Aydın Üniversitesi. Retrieved from https:/ / www.researchgate.net/publication/281098450_STEM_egitimi_Turkiye_raporu_Gunun_modasi_ mi_yoksa_gereksinim_mi_A_report_on_STEM_Education_in_Turkey_A_provisional_agenda_or_a_necess ityWhite_Paper

Akyüz, G. (2006). Teacher and classroom characteristics: Their relationship with mathematics achievement in Turkey, European Union countries and candidate countries (Unpublished doctoral thesis). Middle East Technical University, Ankara, Turkey.

Akyüz, G. (2014). The effects of student and school factors on mathematics achievement in TIMSS 2011. Education and Science, 39(172), 150-162.

Anders, Y., Rossbach, H.-G., Weinert. S., Ebert, S., Kuger, S., Lehrl, S., \& von Maurice, J. (2010). Home and preschool learning environments and their relations to the development of early numeracy skills. Early Childhood Research Quarterly, 27(2), 231-244. https:// doi.org/10.1016/j.ecresq.2011.08.003 
Bahçeşehir University, STEM Center (BAUSTEM). (2018). Integrated teaching project. Retrieved from http:/ / inteach.org

Bandura, A. (1986). Social foundations of thought and action: A social cognitive theory. Englewood Cliffs, NJ: Prentice Hall.

Bronfenbrenner, U. (1994). Ecological models of human development. In T. Husten \& T. N. Postlethwaite (Eds), International encyclopedia of education (2nd ed., Vol. 3, pp. 1643-1647). New York: Elsevier Science.

Brunning, R., \& Horn, C. (2000). Developing motivation to write. Educational Psychologist, 35(1), $25-37$. https:/ / doi.org/10.1207/S15326985ep3501_4

Bryant, S. K. (2017). Self-efficacy sources and academic motivation: A qualitative study of $10^{\text {th }}$ graders (Doctoral dissertation). Retrieved from http:/ / dc.etsu.edu/etd/3231

Byun, S.-y., Schofer, E., \& Kim, K.-k. (2012). Revising the role of cultural capital in east Asian educational systems: The case of South Korea. Sociology of Education, 85(3), 219-239. https:/ / doi.org/10.1177/0038040712447180

Byun, Y.-H., Ha, M., Kwon, H.-J., Choi, K.-H., Burm, E., Choi, Y., . . Kim, N. (2013). Epidemiological characteristics of mobile phone ownership and use in Korean children and adolescents. Environmental Health and Toxicology, 28. https:/ / doi.org/10.5620/eht.2013.28.e2013018

California Department of Education. (2015). Overview of the standards chapters of the mathematics framework for California public schools: Kindergarten through grade twelve. Retrieved from http:/ / www.cde.ca.gov/ci/ma/cf/documents/maathfwoverview.pdf

Carnoy, M., \& Rothstein, R. (2013, January 15). International tests show achievement gaps in all countries, with big gains for U.S. disadvantaged students. Economic Policy Institute. Retrieved from http:/ / www.epi.org/blog/international-tests-achievement-gaps-gains-american-students /

Caponera, E., \& Losito, B. (2016). Context factors and student achievement in the IEA studies: Evidence from TIMSS. Large-scale Assessments in Education, 4(12), 1-22. https:/ / doi.org/10.1186/s40536-016-0030-6

Chen, Q. (2014). Using TIMSS 2007 data to build mathematics achievement model of fourth graders in Hong Kong and Singapore. International Journal of Science and Mathematics Education, 12(6), 1519-1545.

Cheung, A. C. K., \& Slavin, R. E. (2011). The effectiveness of educational technology applications for enhancing mathematics achievement in K-12 classrooms: A meta-analysis. Baltimore, MD: Johns Hopkins University, Center for Research and Reform in Education.

Cheung, A. C. K., \& Slavin, R. E. (2013). The effectiveness of educational technology applications for enhancing mathematics achievement in K-12 classrooms: A meta-analysis. Educational Research Review, 9, 88-113. https:// doi.org/10.1016/j.edurev.2013.01.001

Chiu, M. M. (2010). Effects of inequality, family and school on mathematics achievement: Country and student differences. Social Forces, 88(4), 1645-1676. https:/ / doi.org/10.1353/sof.2010.0019

Choi, J., \& Cho, R. M. (2016). Evaluating the effects of governmental regulations on South Korean private cram schools. Asia Pacific Journal of Education, 36(4), 599-621. https:/ / doi.org/10.1080/02188791.2015.1064356

Claessens, A., Duncan, G., \& Engel, M. (2009). Kindergarten skills and fifth-grade achievement: Evidence from the ECLS-K. Economics of Education Review, 28(4), 415-427. https:/ / doi.org/10.1016/j.econedurev.2008.09.003

Claessens, A., \& Engel, M. (2013). How important is where you start? Early mathematics knowledge and later school success. Teachers College Record, 115(6), 1-29.

Cohen, J., Cohen, P., West, S. G., \& Aiken, L. S. (2003). Applied multiple regression/correlation analysis for the sciences (3rd ed.). Mahwah, NJ: Lawrence Erlbaum Associates.

Common Core State Standards Initiative. (2017). Standards in your state. Retrieved from http:/ / www.corestandards.org/standards-in-your-state/

Council of Chief State School Officers. (2018). Every Student Succeeds Act. Retrieved from https://www.ccsso.org/taxonomy/term/151

DeFlorio, L., \& Beliakoff, A. (2015). Socioeconomic status and preschoolers' mathematical knowledge: The contribution of home activities and parent beliefs. Early Education and Development, 26(3), 319-341. Developmental Psychology, 43(6), 1428-1446. https:/ / doi.org/10.1037/0012-1649.43.6.1428

Douglas, K. A., \& Strobel, J. (2015). Hopes and goals survey for use in STEM elementary education. International Journal of Technology and Design Education, 25(2), 245-259. https:/ / doi.org/10.1007/s10798-014-9277-9

Duncan, G. J., Dowsett, C. J., Claessens, A, Magnuson, K., Huston, A. C., Klebanov, P., . . Japel, C. (2007). School readiness and later achievement. Developmental Psychology, 43(6), 1428-446. https://doi.org/10.1037/00121649.43.6.1428 
ESSA. (2015). Every Student Succeeds Act of 2015, Pub. L. No. 114-95 §114 Sat. 1177 (2015-2016). Retrieved from https://www.congress.gov/114/plaws/pub195/PLAW-114pub195.pdf

Foy, P. (2017). TIMSS 2015 user guide for the international database. Chestnut Hill, MA: TIMSS \& PIRLS International Study Center, Boston College. Retrieved from https://timssandpirls.bc.edu/timss2015/internationaldatabase/

Gottfried, A. E., Fleming, J. S., \& Gottfried, A. W. (1998). Role of cognitively stimulating home environment in children's academic intrinsic motivation: A longitudinal study. Child Development, 69(5), 1448-1460. https:// doi.org/10.1111/j.1467-8624.1998.tb06223.x

Gönener, D. H., Galata, Z., Sertbaş, G., \& Cander, B. (2006). Interaction of mobile phone usage with children. Eurasian Journal of Emergency Medicine, 5, 47-50.

Güvendir, M. A. (2014). Student and school characteristics' relation to Turkish achievement in student achievement determination exam. Education and Science, 39(172), 163-180.

IEA. (2017). TIMSS \& PIRLS. Retrieved from https:/ / timssandpirls.bc.edu/

Jho, H., Hong, O., \& Song, J. (2016). An analysis of STEM/STEAM teacher education in Korea with a case study of two schools from a community of practice perspective. Eurasia Journal of Mathematics, Science and Technology Education, 12(7), 1843-1862. https:// doi.org/10.12973/eurasia.2016.1538a

Kim, S. (2008). Rapid expansion of higher education in South Korea: Political economy of education fever. In D. P. Baker, \& A. W. Wiseman (Eds.), The worldwide transformation of higher education (International perspectives on education and society, Vol. 9, pp. 223-268). Bingley, UK: Emerald Group Publishing Limited.

Kim, H., \& Chae, D. (2016). The development and application of a STEAM program based on traditional Korean culture. Eurasia Journal of Mathematics, Science and Technology Education, 12(7), 1925-1936. https:// doi.org/10.12973/eurasia.2016.1539a

Kim, Y. H., Lee, I. H., \& Park, H. J. (1993). A study of Koreans' educational enthusiasm. Seoul: Korean Educational Development Institute.

Kim, J., \& Park, D. (2010). The determinants of demand for private tutoring in South Korea. Asia Pacific Education Review, 11(3), 411-421. https:/ / doi.org/10.1007/s12564-009-9067-3

Korean Ministry of Education. (2017a). Statistics. Retrieved from http:/ / english.moe.go.kr/sub/info.do?m=050101\&page=050101\&num=1\&s=english

Korean Ministry of Education. (2017b). Major Tasks. Retrieved from http:/ / english.moe.go.kr/sub/info.do?m=040101\&s=english

Lee, C. (2005). Korean education fever and private tutoring. KEDI Journal of Educational Policy, 2(1), 99-107. Retrieved from https://www.kedi.re.kr/khome/main/journal/selectJournalForm.do?maxLinks=10\&maxResults= 10\&currentPage $=1 \&$ plNum0 $=5124 \&$ plKind $=E J$

Lee, J. (2007). Two worlds of private tutoring: The prevalence and causes of after-school mathematics tutoring in Korea and the United States. Teachers College Record, 109(5), 1207-1234. Retrieved from https:/ / pdfs.semanticscholar.org/5765/0861777d3e6486774100bd4d66c09be0d537.pdf

Lee, J. K. (2003). Korean higher education: A Confucian perspective. Edison, NJ: Jimoondang International.

Lee, J. K. (2006). Educational fever and South Korean higher education. Revista Electronica de Investigacion Educativa (REDIE), 8(1). Retrieved from http:/ / redie.uabc.mx/vol8no1/contents-lee2.html

Leung, F. K. S. (2001). In search of an East Asian identity in mathematics education. Educational Studies in Mathematics, 47(1), 35-51. https:/ / doi.org/10.1023/A:1017936429620

Leung, F. K. S. (2006). Mathematics education in East Asia and the West: Does culture matter? In F. K. S. Leung, K.D. Graf, \& F. J. Lopez-Real (Eds.), Mathematics education in different cultural traditions: A comparative study of East Asia and the West: The 13 th ICMI study (pp. 21-46). Boston, MA: Springer US. https:/ / doi.org/10.1007/0387-29723-5_2

Linn, M. C., Lewis, C., Tsuchida, I., \& Songer, N. B. (2000). Beyond fourth-grade science: Why do U.S. and Japanese students diverge? Educational Researcher, 29(3), 4-14. https:/ / doi.org/10.3102/0013189X029003004

Livingstone, S., Mascheroni, G., Dreier, M., Chaudron, S., \& Lagae, K. (2015). How parents of young children manage digital devices at home: The role of income, education and parental style. London: EU Kids Online, LSE.

Lubinski, D., Benbow, C. P., \& Kell, H. J. (2014). Life paths and accomplishments of mathematically precocious males and females four decades later. Psychological Science, 25, 2217-2232. https:/ / doi.org/10.1177/0956797614551371

Malin, J. R., Bragg, D. D., \& Hackmann, D. G. (2017). College and career readiness and the Every Student Succeeds Act. Educational Administration Quarterly, 53(5), 809-838. https:/ / doi.org/10.1177/0013161X17714845 
Malley, L., Neidorf, T., Arora, A., \& Kroeger, T. (2016). United States. In I. V. S. Mullis, M. O. Martin, S. Goh, \& K. Cotter (Eds.) (2016). TIMSS 2015 encyclopedia: Education policy and curriculum in mathematics and science. Retrieved from http:/ / timssandpirls.bc.edu/timss2015/encyclopedia/

Manolitsis, G., Georgiou, G. K., \& Tziraki, N. (2013). Examining the effects of home literacy and numeracy environment on early reading and math acquisition. Early Childhood Research Quarterly, 28(4), 692-703. https:// doi.org/10.1016/j.ecresq.2013.05.004

Melhuish, E. C., Phan, M. B., Sylva, K., Sammons, P., Siraj-Blatchford, I., \& Taggart, B. (2008). Effects of the home learning environment and preschool center experience upon literacy and numeracy development in early primary school. Journal of Social Issues, 64(1), 95-114. https:/ / doi.org/10.1111/j.1540-4560.2008.00550.x

Min, I., Cortina, K. S., \& Miller, K. F. (2016). Modesty bias and the attitude-achievement paradox across nations: A reanalysis of TIMSS. Learning and Individual Differences, 51, 359-366. https:/ / doi.org/10.1016/j.lindif.2016.09.008

Ministry of National Education. (2018). National education statistics, Formal education 2017/'18. Retrieved from http:/ /sgb.meb.gov.tr/meb_iys_dosyalar/2018_09/06123056_meb_istatistikleri_orgun_egitim_2017_2018. pdf

Ministry of National Education, General Directorate of Innovation and Educational Technologies (YEĞITTEK). (2016). STEM education report. Retrieved from http://yegitek.meb.gov.tr/STEM_Education_Report.pdf

Ministry of National Education, General Directorate of Innovation and Educational Technologies (YEĞITTEK). (2017). EBA'da düşün, tasarla, kodla... [Think, design, and code on the educational informatics network]. Retrieved from http:/ / yegitek.meb.gov.tr/www/ebada-dusun-tasarla-kodla/icerik/1161

Ministry of National Education, General Directorate of Innovation and Educational Technologies (YEĞITEK). (2018). STEM egitimi ögretmen el kitabi [STEM education teacher's handbook]. Retrieved from http:/ / scientix.meb.gov.tr/images/upload/Event_35/Gallery/STEM\%20Eğitimi\%20Öğretmen\%20El\%20 Kitabi.pdf

Mullis, I. V. S., Martin, M. O., Foy, P., \& Arora, A. (2012). TIMSS 2011 international results in mathematics. Chestnut Hill, MA: TIMSS \& PIRLS International Study Center, Boston College.

Mullis, I. V. S., Martin, M. O., Foy, P., \& Hooper, M. (2016). TIMSS 2015 international results in mathematics. Retrieved from http:/ / timssandpirls.bc.edu/timss2015/international-results /

National Center for Education Statistics. (2017). Back to school statistics. Retrieved from https:/ / nces.ed.gov/fastfacts / display.asp?id=372

National Science and Technology Council. (2011). The federal science, technology, engineering, and mathematics (STEM education portfolio). Retrieved from https://www.whitehouse.gov/sites/default/files/microsites/ostp/ costem_federal_stem_education_portfolio_report.pdf

OECD. (2015). Students, computers and learning: Making the connection. Paris, France: PISA, OECD Publishing. https:// doi.org/10.1787/9789264239555-en

OECD. (2016a). Education Policy Outlook: Korea. Retrieved from www.oecd.org/education/policyoutlook.htm

OECD. (2016b). Programme for International Student Assessment. Retrieved from http://www.oecd.org/pisa/

Okagaki, L., \& Frensch, P. A. (1998). Parenting and children's school achievement: A multiethnic perspective. American Educational Research Journal, 35(1), 123-144. https:/ / doi.org/10.3102/00028312035001123

Ordoñez, V., \& Maclean, R. (1997). Asian: The Impact of educational research on decision making. Prospects, XXVII(4), 645-654. https:/ / doi.org/10.1007/BF02736608

Özdemir, E., Gönen, E., Polat, M., \& Akyüz Ari, S. (2016). Turkey. In I. V. S. Mullis, M. O. Martin, S. Goh, \& K. Cotter (Eds.) (2016). TIMSS 2015 encyclopedia: Education policy and curriculum in mathematics and science. Retrieved from http:/ / timssandpirls.bc.edu/timss2015/encyclopedia/

Paik, S. J. (2004). Korean and U.S. families, schools, and learning. International Journal of Educational Research, 41, 7190. https://doi.org/10.1016/j.ijer.2005.04.006

Papanastasiou, C. (2000). Effects of attitudes and beliefs on mathematics achievement. Studies in Educational Evaluation, 26(1), 27-42. https:/ / doi.org/10.1016/S0191-491X(00)00004-3

Park, Y.-S., \& Kim, U. (2006). Family, parent-child relationship, and academic achievement in Korea: Indigenous, cultural, and psychological analysis. In U. Kim, K. S. Yang, \& K. K. Hwang (Eds.), Indigenous and cultural psychology: Understanding people in context (pp. 421-443). New York, NY: Springer. https:/ / doi.org/0.1007/0387-28662-4_19 
Poll, H. (2014). Pearson student mobile device survey 2014. [PDF document]. Retrieved from https:/ / www.pearsoned.com/wp-content/uploads/2015-Pearson-Student-Mobile-Device-SurveyGrades-4-12.pdf

Pouezevara, S., Dincer, A., Kipp, S., \& Sariisik, Y. (2013). Turkey's FATIH project: A plan to conquer the digital divide or a technological leap of faith? Research Triangle Park, NC \& Istanbul, Turkey: RTI International \& Education Reform Initiative (ERI).

Ramirez, M. J. (2006). Understanding the low mathematics achievement of Chilean students: A cross-national analysis using TIMSS data. International Journal of Educational Research 45, 102-116. https:/ / doi.org/10.1016/j.ijer.2006.11.005

Ritchie, S. J., \& Bates, T. C. (2013). Enduring links from childhood mathematics and reading achievement to adult socioeconomic status. Psychological Science, 24(7), 1301-1308. https:/ / doi.org/10.1177/0956797612466268

Rosenthal, T. L., \& Zimmerman, B. J. (1978). Social learning and cognition. New York, NY: Academic Press.

Rowan-Kenyon, H., Swan, A. K., \& Creager, M. F. (2012). Social cognitive factors, support, and engagement: Early adolescents' math interests as precursors to choice of career. The Career Development Quarterly, 60(1), 2-15. https:/ / doi.org/10.1002/j.2161-0045.2012.00001.x

Sang, K., Kwak, Y., Park, S., \& Park, J. H. Korea, Rep. of. In I. V. S. Mullis, M. O. Martin, S. Goh, \& K. Cotter (Eds.) (2016). TIMSS 2015 encyclopedia: Education policy and curriculum in mathematics and science. Retrieved from http:/ / timssandpirls.bc.edu/timss2015/encyclopedia/

Siegler, R. S., Duncan, G. J., Davis-Kean, P. E., Duckworth, K., Claessens, A., Engel, M., . . Chen, M. (2012). Early predictors of high school mathematics achievement. Psychological Science, 23(7), 691-697. https:/ / doi.org/10.1177/0956797612440101

Skryabin, M., Zhang, J., Liu, L., \& Zhang, D. (2015). How the ICT development level and usage influence student achievement in reading, mathematics, and science. Computers $\mathcal{E}$ Education, 85, 49-58. https:/ / doi.org/10.1016/j.compedu.2015.02.004

Stevenson, H., \& Stigler, J. (1992). The learning gap: Why our schools are failing and what we can learn from Japanese and Chinese education. New York: Summit Books.

Talim ve Terbiye Kurulu Başkanlığı. (2018). Matematik dersi öğretim programı (Ilkokul ve ortaokul 1, 2, 3, 4, 5, 6, 7 ve 8. Siniflar) [Mathematics instruction plan (Elementary and Middle School $1^{\text {st }}, 2^{\text {nd }}, 3^{\text {td }}, 4^{\text {th }}, 5^{\text {th }}, 6^{\text {th }}, 7^{\text {th }}$ and $8^{\text {th }}$ grades)]. Retrieved from http:/ / mufredat.meb.gov.tr/ProgramDetay.aspx?PID=329

The IEA International Database Analyzer (IDB Analyzer, Version 3.1) [Computer software] (2013). Hamburg, Germany: International Association for the Evaluation of Educational Achievement.

Topçu, M. S., Erbilgin, E., \& Arıkan, S. (2016). Factors predicting Turkish and Korean students' science and mathematics achievement in TIMSS 2011. Eurasia Journal of Mathematics, Science and Technology Education, 12(7), 1711-1737. https:// doi.org/10.12973/eurasia.2016.1530a

U.S. Department of Education. (2015, March). Science, technology, engineering and math: Education for Global Leadership. Retrieved from https://www.ed.gov/stem

Wang, D. B. (2004). Family background factors and mathematics success: A comparison of Chinese and US students. International Journal of Educational Research, 41(1), 40-54. https:/ / doi.org/10.1016/j.ijer.2005.04.013

$\mathrm{Xu}, \mathrm{J}$. (2015). Investigating factors that influence conventional distraction and tech-related distraction in math homework. Computers \& Education, 81, 304-314. https:// doi.org/10.1016/j.compedu.2014.10.024

Yayan, B., \& Berberoglu, G. (2004). A re-analysis of the TIMSS 1999 mathematics assessment data of the Turkish students. Studies in Educational Evaluation, 30(1), 87-104. https://doi.org/10.1016/S0191-491X(04)90005-3

Zhu, Y., \& Leung, F. K. S. (2011). Motivation and achievement: Is there an East Asian model? International Journal of Science and Mathematics Education 9(5), 1189-1212. https://doi.org/10.1007/s10763-010-9255-y

Zhu, Y., \& Leung, F. K. S. (2012). Homework and mathematics achievement in Hong Kong: Evidence from the TIMSS 2003. International Journal of Science and Mathematics Education, 10(4), 907-925. https:/ / doi.org/10.1007/s10763-011-9302-3

Zimmerman, B. J. (2000). Self-efficacy: An essential motive to learn. Contemporary Educational Psychology, 25(1), 8291. https:/ / doi.org/10.1006/ceps.1999.1016

Zimmerman, B. J., \& Schunk, D. H. (2003). Albert Bandura: The scholar and his contributions to educational psychology. In B. J. Zimmerman \& D. H. Schunk (Eds.), Educational psychology: A century of contributions (pp. 431-457). Mahwah, NJ, US: Lawrence Erlbaum Associates Publishers.

\section{http://www.ejmste.com}

